Article

\title{
Unsymmetrical Mesoporphyrinic Complexes of Copper (II) and Zinc (II). Microwave-Assisted Synthesis, Spectral Characterization and Cytotoxicity Evaluation
}

\section{Rica Boscencu}

Faculty of Pharmacy, "Carol Davila" University of Medicine and Pharmacy, 6 Traian Vuia St., 020956 Bucharest, Romania; E-Mail: rboscencu@yahoo.com; Tel.: +4021-3111152; Fax: +4021-3111152

Received: 16 May 2011; in revised form: 27 June 2011 / Accepted: 29 June 2011 /

Published: 30 June 2011

\begin{abstract}
New unsymmetrical mesoporphyrinic complexes, namely 5-(4-hydroxyphenyl)10,15,20-tris-(4-carboxymethylphenyl)-21,23-Zn(II)-porphine and 5-(4-hydroxyphenyl)10,15,20-tris-(4-carboxymethylphenyl)-21,23-Cu(II)-porphine, were synthesized using a microwave irradiation method. The structures of the porphyrinic complexes were confirmed using FT-IR, UV-Vis, EPR and NMR spectral data. The spectral absorption and emission properties of the porphyrinic complexes were studied in organic solvents of different polarities and the influence of solvent polarity on the wavelengths of the absorbance and fluorescence band maxima is described. The cytotoxicity evaluation of the porphyrinic complexes was performed on human colon adenocarcinoma cell line HT29 for different doses and incubation times. The obtained result indicates a lack of or low toxicity for both compounds, thus recommending them for further testing in light activation protocols.
\end{abstract}

Keywords: unsymmetrical mesoporphyrinic complexes; microwave irradiation; solvatochromy; cytotoxicity; HT29 cell line

\section{Introduction}

Metalloporphyrins have attracted attention for many decades because of their importance in the field of biomedicine, especially in diagnosis and treatment of cancer [1-6] as well as in photodynamic antimicrobial therapy [7-10]. 
Photodynamic therapy as a selective treatment method that involves the administration of a pharmaceutical formulation containing a tetrapyrrolic photosensitizer, its selective localization at the cellular level, followed by generation by irradiation with light in the red region of the visible spectrum of cytotoxic species such as singlet oxygen $\left({ }^{1} \mathrm{O}_{2}\right)$ that destroys the sick cells [11-15]. The development of new candidates for potential application as sensitizers in photodynamic therapy requires of them a high purity and simple production under laboratory conditions, a good localization at cellular and subcellular level, great selectivity for the malignant tissue, photoactivity at wavelengths higher than $600 \mathrm{~nm}$, lack of toxicity in the absence of the exciting light, rapid elimination from the body after the treatment is performed and nontoxic metabolites [16-21].

Porphyrins and metalloporphyrins have also been investigated for use as fluorescent markers in cancer diagnosis because have appropriate fluorescence characteristics such as convenient emissions in the phototherapeutic window ( $\sim 60$ to $1,100 \mathrm{~nm}$ ), high singlet oxygen quantum yield, large Stokes shifts, and reduced photolability $[1,3,4]$. For diagnostic and photodynamic therapeutic applications the biomedical efficiency of the porphyrinic structures is determined by its subcellular localization, which depends on the structural and physicochemical characteristics of the photosensitizer [22]. Therefore, depending on the nature of the peripheric substituents and the metallic ion, photosensitizers can be localized within the mitochondria, lysosomes, endoplasmic reticulum, Golgi apparatus and plasma membranes [23]. Thus, by modifying the charge density and its distribution at the periphery of the tetrapyrrolic macrocycle it is possible to control the route of these compounds to the target cells $[24,25]$. The purity of these compounds is also very important because the presence of trace amounts of impurities can introduce significant errors in the photodynamic activity.

This paper reports the microwave-assisted synthesis of some new unsymmetrical porphyrinic complexes, namely 5-(4-hydroxyphenyl)-10,15,20-tris-(4-carboxymethylphenyl)-21,23-Zn(II)-porphine (denoted as $\mathrm{Zn}(\mathrm{II}) \mathrm{TCMPOH}_{\mathrm{p}}$ - Figure 1) and 5-(4-hydroxyphenyl)-10,15,20-tris-(4-carboxymethylphenyl)-21,23-Cu(II)-porphine (denoted as $\mathrm{Cu}(\mathrm{II}) \mathrm{TCMPOH}_{\mathrm{p}}$ - Figure 1), their spectral properties and cytotoxicity evaluation with a view to assessing their possible use in the photodiagnosis and photodynamic therapy of cancer.

Figure 1. General structures of 5-(4-hydroxyphenyl)-10,15,20-tris-(4-carboxymethylphenyl)-21, $23 \mathrm{M}(\mathrm{II})$ porphines.
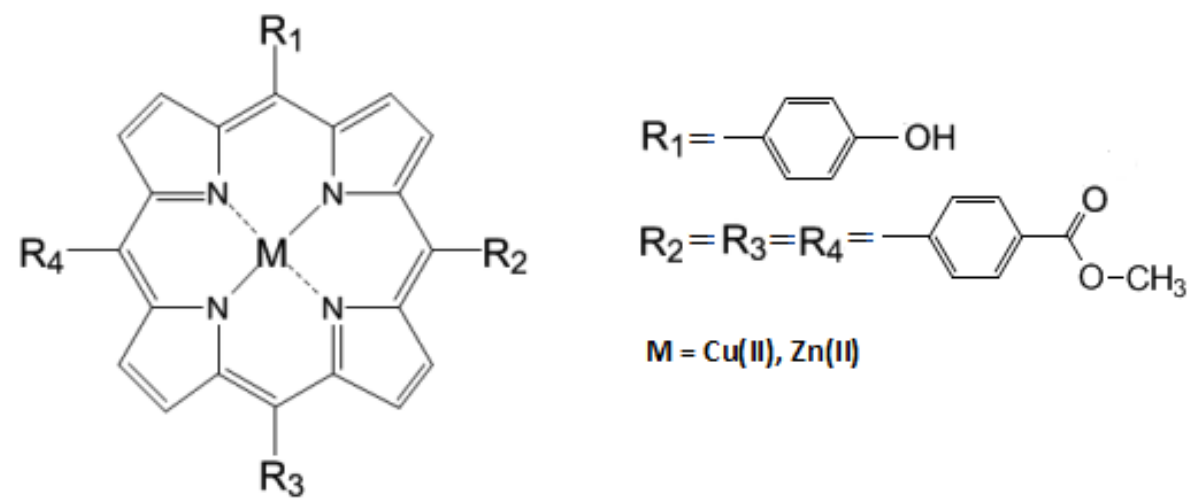

$\mathrm{M}=\mathrm{Cu}(\mathrm{II}), \mathrm{Zn}(\mathrm{II})$

5-(4-hydroxyphenyl)-10,15,20-tris-(4-carboxymethylphenyl)-21,23-Zn(II)-porphine, (Zn(II)TCMPOH ${ }_{\mathrm{p}}$ ),

5-(4-hydroxyphenyl)-10,15,20-tris-(4-carboxymethylphenyl)-21,23-Cu(II)-porphine, (Cu(II)TCMPOH $\left.{ }_{\mathrm{p}}\right)$ 


\section{Results and Discussion}

Microwave assisted synthesis has attracted considerable attention over the last few years and has been applied successfully in the preparation of tetrapyrrolic complexes. The main advantages of synthesis via microwave irradiation are significant reductions in reaction times and side reactions, increased yields, ease of purification and minimization of the amount of solvent used [26-31]. For thse these reasons in this paper the synthesis of the porphyrinic complexes was carried out using microwave irradiation assisted synthesis. The synthetic reactions have been successfully repeated several times with identical results and the porphyrinic complexes thus formed were then characterized by elemental analysis, IR, UV-Vis, NMR, EPR spectrometry and evaluated in terms of cytotoxicity using HT29 (human colon adenocarcinoma) cell line for different doses and incubation times.

\subsection{Infrared Spectra}

The most relevant results extracted from the IR spectra of the synthesized unsymmetrical porphyrinic complexes are presented in Table 1.

Table 1. Characteristic IR vibrations of the unsymmetrical porphyrinic complexes.

\begin{tabular}{lcc}
\hline $\begin{array}{l}\text { Characteristic } \\
\text { vibration }\end{array}$ & \multicolumn{2}{c}{ Wavenumber of the IR band $\left.\mathbf{c m}^{-\mathbf{1}}\right)$} \\
\cline { 2 - 3 }$v_{\mathrm{O}-\mathrm{H}}$ & $\mathbf{Z n ( I I ) T C M P O H} \mathbf{p H}_{\mathbf{p}}$ & $\mathbf{C u}_{\mathbf{I I}) \mathbf{T C M P O H}}$ \\
$v_{\mathrm{C}-\mathrm{H}}$ & $3490 \mathrm{~m}$ & $3489 \mathrm{~m}$ \\
$v_{\mathrm{C}-\mathrm{H} \text { from -O-CH3 }}$ & $2919 \mathrm{~m}$ & $2920 \mathrm{~m}$ \\
$v_{\mathrm{C}=\mathrm{O}}$ & $2850 \mathrm{~m}$ & $2850 \mathrm{~m}$ \\
$v_{\mathrm{C}-\mathrm{N}}$ & $1716 \mathrm{~m}$ & $1718 \mathrm{~m}$ \\
$v_{\mathrm{C}=\mathrm{N}}$ & $1595 \mathrm{~s}$ & $1596 \mathrm{~s}$ \\
$v_{\mathrm{C}-\mathrm{H} \text { pyrrole }}$ & $1451 \mathrm{~m}$ & $1453 \mathrm{~m}$ \\
$v_{\mathrm{C}-\mathrm{O}}$ & $1390 \mathrm{~m}$ & $1384 \mathrm{w}$ \\
$\delta_{\mathrm{C}-\mathrm{H}}$ & $1158 \mathrm{~m}$ & $1157 \mathrm{~m}$ \\
$\gamma_{\mathrm{C}-\mathrm{C}}$ & $1029 \mathrm{~m}$ & $1032 \mathrm{w}$ \\
$\gamma_{\mathrm{C}-\mathrm{N} \text { pyrrole }}$ & $859 \mathrm{w}$ & $857 \mathrm{w}$ \\
\hline
\end{tabular}

The intensities of the signals are described as weak $(w)$, medium $(m)$, strong $(s)$ and very strong (v.s.).

The IR spectra of the porphyrinic ligand [32] shows a medium band at $\sim 3,310 \mathrm{~cm}^{-1}$ assigned to the $\mathrm{N}-\mathrm{H}$ stretching vibration of the porphyrinic core, which not found in the spectrum of the mesoporphyrinic complexes. This observation supports the coordination of both nitrogen atoms of the porphyrinic core to the metal center.

The IR spectrum of the synthesized copper and zinc complexes includes typical vibration modes of both porphyrin macrocycle and phenyl substituents. Thus, the medium band at $2,919 \mathrm{~cm}^{-1}$ is attributed to the $\mathrm{C}-\mathrm{H}$ stretching of the phenyl groups. The bands at $3,490 \mathrm{~cm}^{-1}$ are assigned to the $\mathrm{O}-\mathrm{H}$ stretching vibration of the $-\mathrm{OH}$ functional group in the $\mathrm{Zn}(\mathrm{II}) \mathrm{TCMPOH}_{\mathrm{P}}$ and $\mathrm{Cu}(\mathrm{II}) \mathrm{TCMPOH}$. The bands of the complexes in the range of $1,716-1,718 \mathrm{~cm}^{-1}$ are assigned to $\mathrm{C}=\mathrm{O}$ stretching vibrations. In addition, in the IR spectra of the unsymmetric porphyrinic complexes the medium absorption band at about $1,158 \mathrm{~cm}^{-1}$ can be attributed to the C-O groups. The IR spectrum of the porphyrinic complexes 
indicates the presence of the $-\mathrm{O}-\mathrm{CH}_{3}$ group at $2,850 \mathrm{~cm}^{-1}$. A band attributed to $v_{\mathrm{C}=\mathrm{N}}$ was present at 1,451-1,453 $\mathrm{cm}^{-1}$. In addition, the band at about $1,595 \mathrm{~cm}^{-1}$ can be assigned to $\mathrm{C}-\mathrm{N}$ stretching vibrations and the band at $\sim 1,390 \mathrm{~cm}^{-1}$ includes the $\mathrm{C}-\mathrm{H}$ stretching of the pyrrole ring.

\subsection{Absorption and Fluorescence Spectra}

The absorption spectra of $\mathrm{Zn}(\mathrm{II}) \mathrm{TCMPOH}_{\mathrm{p}}$ and $\mathrm{Cu}(\mathrm{II}) \mathrm{TCMPOH}_{\mathrm{p}}$ were studied in solvents with different polarities (methanol, ethanol, isopropyl alcohol, dimethyl sulfoxide, dimethylformamide, dichloromethane) for solutions containing $2.5 \times 10^{-6} \mathrm{M}$ of the porphyrinic complex. The obtained results are presented in Figures 2 and 3 and Table 2.

Figure 2. Absorption spectra of 5-(4-hydroxyphenyl)-10,15,20-tris-(4-carboxymethylphenyl) $-21,23 \mathrm{Zn}(\mathrm{II})$ porphine in different solvents $\left(\mathrm{c}=2.5 \times 10^{-6} \mathrm{M}\right.$, a-Soret band; b-Q bands).
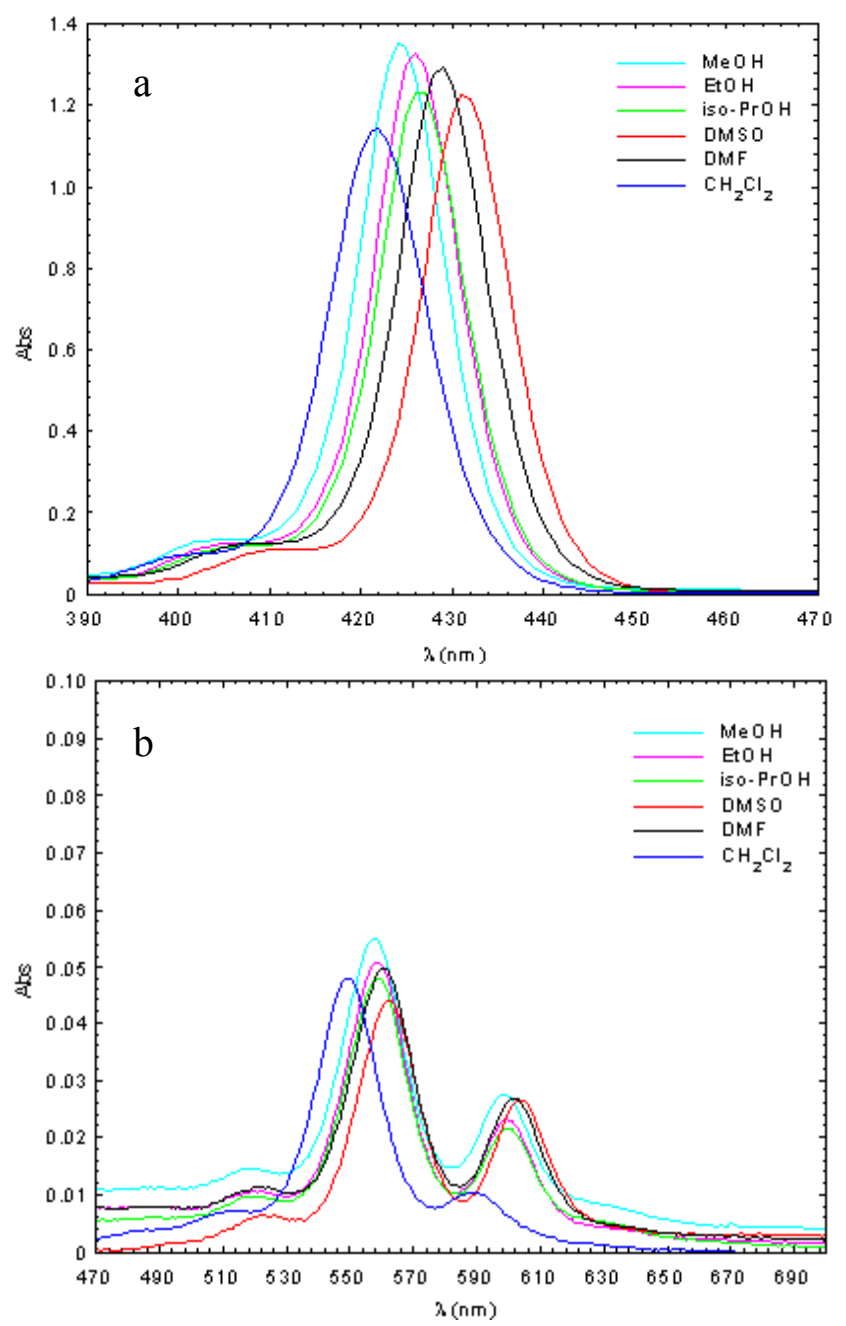
Figure 3. Absorption spectra of 5-(4-hydroxyphenyl)-10,15,20-tris-(4-carboxymethylphenyl) $-21,23 \mathrm{Cu}$ (II) porphine in different solvents $\left(\mathrm{c}=2.5 \times 10^{-6} \mathrm{M}\right.$, a-Soret band; b-Q bands).
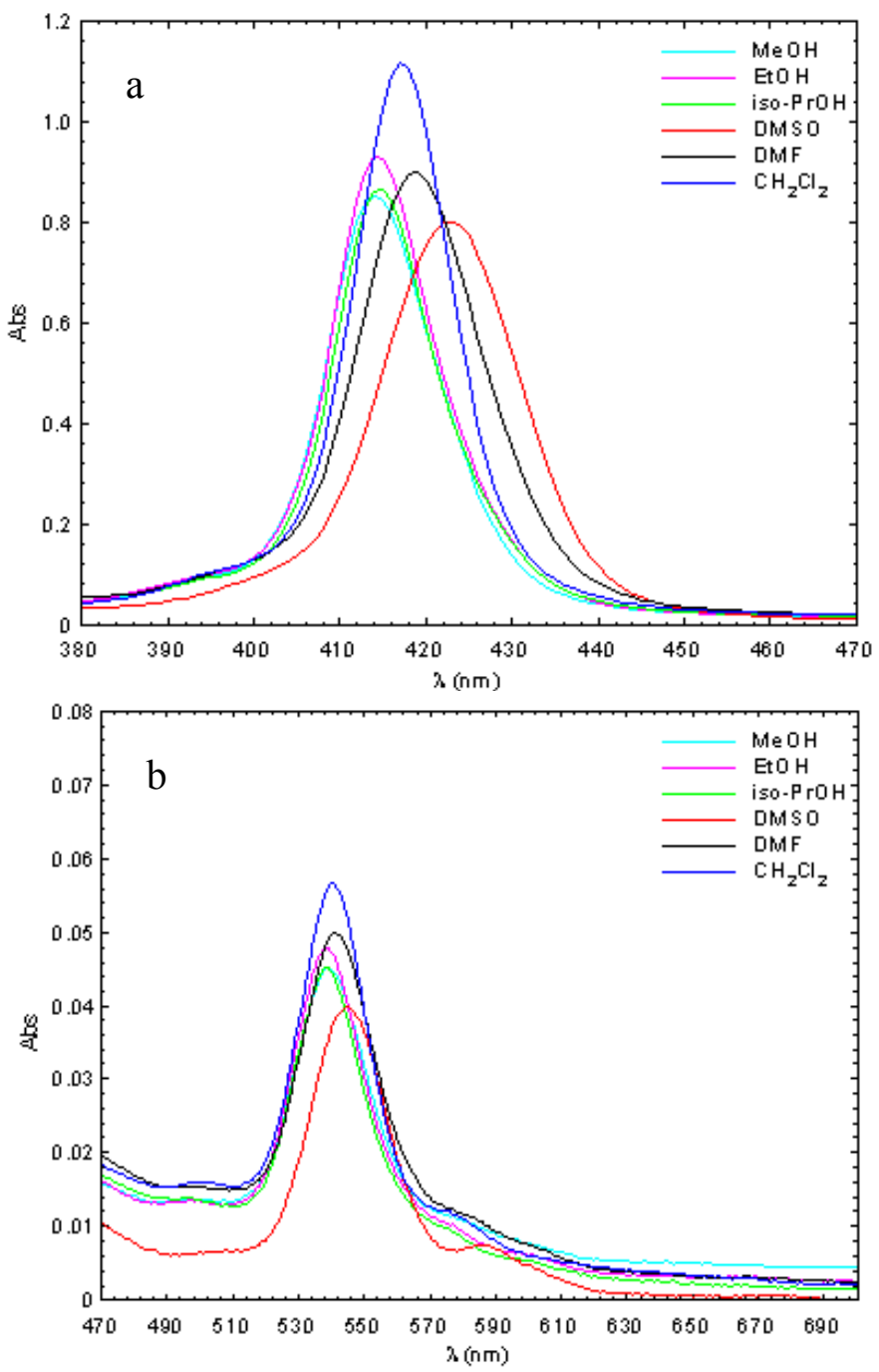

Table 2. Maximum wavelength and molar absorptivity of the $\mathrm{Zn}(\mathrm{II}) \mathrm{TCMPOH}_{\mathrm{p}}$ and $\mathrm{Cu}(\mathrm{II}) \mathrm{TCMPOH}_{\mathrm{p}}$ in different solvents $\left(\mathrm{c}=2.5 \times 10^{-6} \mathrm{M}\right)$.

\begin{tabular}{|c|c|c|c|}
\hline \multirow{3}{*}{ Solvent } & \multicolumn{3}{|c|}{$\lambda_{\max }(\mathrm{nm})\left[\lg \varepsilon\left(\mathrm{L} \mathrm{mol}^{-1} \mathrm{~cm}^{-1}\right)\right]$} \\
\hline & \multirow{2}{*}{$\begin{array}{c}\text { Soret band } \\
\mathbf{B}(\mathbf{0 , 0})\end{array}$} & \multicolumn{2}{|c|}{ Q bands } \\
\hline & & $Q_{\mathbf{y}}(\mathbf{0 , 0})$ & $Q_{x}(\mathbf{1}, \mathbf{0})$ \\
\hline \multicolumn{4}{|c|}{ 5-(4-hydroxyphenyl)-10, 15, 20-tris-(4-carboxymethylphenyl)-21,23-Zn(II) porphine } \\
\hline $\mathrm{MeOH}$ & $424.5[5.732]$ & $557.7[4.342]$ & 598.8 [4.049] \\
\hline $\mathrm{EtOH}$ & $426.0[5.723]$ & $558.6[4.310]$ & $599.7[3.964]$ \\
\hline iso-PrOH & $426.7[5.693]$ & $558.6[4.283]$ & $600.0[4.033]$ \\
\hline $\mathrm{CH}_{2} \mathrm{Cl}_{2}$ & $421.9[5.659]$ & $549.1[4.282]$ & $588.6[3.602]$ \\
\hline DMF & $428.9[5.713]$ & $560.7[4.301]$ & $601.8[4.033]$ \\
\hline DMSO & $431.5[4.954]$ & $562.8[4.246]$ & $603.6[4.028]$ \\
\hline
\end{tabular}


Table 2. Cont.

\begin{tabular}{lccc}
\hline \multicolumn{4}{c}{ 5-(4-hydroxyphenyl)-10, 15, 20-tris-(4-carboxymethylphenyl)-21,23-Cu(II) porphine } \\
\hline $\mathrm{MeOH}$ & $414.2[5.532]$ & $538.6[4.260]$ & - \\
$\mathrm{EtOH}$ & $414.5[5.571]$ & $538.9[4.283]$ & - \\
iso-PrOH & $414.8[5.540]$ & $538.9[4.259]$ & - \\
$\mathrm{CH}_{2} \mathrm{Cl}_{2}$ & $417.1[5.649]$ & $540.1[4.356]$ & - \\
$\mathrm{DMF}$ & $418.8[5.555]$ & $541.3[4.298]$ & $578.1(\mathrm{sh})$ \\
$\mathrm{DMSO}$ & $422.9[5.507]$ & $545.2[4.203]$ & $587.4[3.477]$ \\
\hline
\end{tabular}

sh - shoulder; $\mathrm{MeOH}=$ methanol, $\mathrm{EtOH}=$ ethanol, iso-PrOH $=$ isopropyl alcohol, $\mathrm{DMF}=$ dimethylformamide, $\mathrm{CH}_{2} \mathrm{Cl}_{2}=$ dichloromethane, $\mathrm{DMSO}=$ dimethyl sulfoxide.

The obtained molecular electronic spectra of the copper and zinc synthesized complexes are typical of metalloporphyrins [33-37]. These consist of the Soret band, as a result of the $\mathrm{a}_{1 \mathrm{u}}(\pi) \rightarrow \mathrm{e}_{\mathrm{g}}(\pi *)$ transition and two $\mathrm{Q}$ bands bands corresponding to the $\mathrm{a}_{2 \mathrm{u}}(\pi) \rightarrow \mathrm{e}_{\mathrm{g}}(\pi *)$ transition.

Thus, the UV-Vis spectra of the $\mathrm{Zn}(\mathrm{II}) \mathrm{TCMPOH}_{\mathrm{p}}$ complex exhibited one Soret band in the spectral range of 421-432 nm accompanied by two Q bands, in the 549-563 nm and 588-604 nm spectral range, respectively. The absorption spectra of $\mathrm{Cu}(\mathrm{II}) \mathrm{TCMPOH}_{\mathrm{p}}$ display a Soret band in the $414-423 \mathrm{~nm}$ wavelength region and either one or two Q bands between 538-590 nm, depending on solvent polarity.

The main differences observed in the absorption spectra of the two porphyrinic complexes are determined by the nature of the metallic center and solvent polarity. Thus, in the absorption spectra of metalloporphyrinic complexes in various solvents, a blue shift of the spectral bands was observed with increasing solvent polarity [38]. These spectral changes can be ascribed to the formation of proton bridges between the polar solvent molecules and the porphyrinic substitutents due to the polarityinduced and proton properties of the alcohol. Also, from the absorption spectra of copper porphyrin can be observed that the second Q band has much smaller intensity or disappeared with increasing solvent polarity.

Compared with $\mathrm{Zn}(\mathrm{II}) \mathrm{TCMPOH}_{\mathrm{p}}$, the spectral bands of the $\mathrm{Cu}(\mathrm{II}) \mathrm{TCMPOH}$ shows a blue shift around 10-12 nm for the Soret band and about $20 \mathrm{~nm}$ for Q bands. In agreement with Gouterman's theory [39], these spectral differences can be explained by stronger conjugation effects for the copper $4 p_{z}$ orbital with the $\pi$ electrons of the tetrapyrrolic ring, effects that cause a decrease the energy of the $\mathrm{a}_{1 \mathrm{u}}(\pi)$ and $\mathrm{a}_{2 \mathrm{u}}(\pi)$ orbitals relative to the $\mathrm{e}_{\mathrm{g}}\left(\pi^{*}\right)$ orbitals with increased energy available for electron transitions and the blue shift of the spectral bands.

Of the synthesized metalloporphyrins, fluorescence signals were only detected for $\mathrm{Zn}(\mathrm{II}) \mathrm{TCMPOH}_{\mathrm{p}}$ under the experimental conditions used. The emission spectra of 5-(4-hydroxyphenyl)-10,15,20-tris(4-carboxymethylphenyl)-21,23-Zn(II) porphine in different solvents, at room temperature, were recorded at $\lambda_{\text {ex }}=420 \mathrm{~nm}$.

The fluorescence spectral data shows for $\mathrm{Zn}(\mathrm{II}) \mathrm{TCMPOH}_{\mathrm{p}}$ two bands located in the 605-660 nm spectral region (see Table 3) and reveal smaller shifts of the emmision maxima by changing the solvent polarity. 
Table 3. The fluorescence data of $\mathrm{Zn}(\mathrm{II}) \mathrm{TCMPOH}_{\mathrm{p}}\left(\mathrm{c}=2.5 \times 10^{-6} \mathrm{M}, \lambda_{\mathrm{ex}}=420 \mathrm{~nm}\right)$.

\begin{tabular}{ccc}
\hline \multirow{2}{*}{ Solvent } & \multicolumn{2}{c}{$\left.\boldsymbol{\lambda}_{\mathbf{m a x}}(\mathbf{n m})\left[\mathbf{I}_{\mathbf{f}}\right] \mathbf{( a . u .}\right)$} \\
\cline { 2 - 3 } $\mathrm{MeOH}$ & $605.2[379.3]$ & $\mathbf{Q}_{\mathbf{x}}(\mathbf{0 , 1})$ \\
$\mathrm{EtOH}$ & $606.8[740.2]$ & $651.8[63.2]$ \\
$i s o-\mathrm{PrOH}$ & $607.0[776.8]$ & $651.6[118.0]$ \\
$\mathrm{CH}_{2} \mathrm{Cl}_{2}$ & $608.9[585.5]$ & $653.1[126.4]$ \\
$\mathrm{DMF}$ & $609.7[490.7]$ & $653.5[130.7]$ \\
$\mathrm{DMSO}$ & $610.9[380.8]$ & $654.9[81.5]$ \\
\hline
\end{tabular}

$\mathrm{MeOH}=$ methanol, $\mathrm{EtOH}=$ ethanol, iso $-\mathrm{PrOH}=$ isopropyl alcohol, $\mathrm{DMF}=$ dimethylformamide, $\mathrm{CH}_{2} \mathrm{Cl}_{2}=$ dichloromethane, $\mathrm{DMSO}=$ dimethyl sulfoxide.

\subsection{Dark Cytotoxicity Tests}

The short-term cytotoxicity evaluation of a metalloporphyrinic compound designed to be used as a photosensitizer is mandatory for its efficiency validation in antitumor therapy when seeking a new therapeutic agent [40] and of its use in imagistics [41]. As well, a long incubation period with the porphyrinic complexes structures provides the answer to the question concerning the possibility of a delayed cytotoxicity installation in the cells when the phototherapeutic aim is the objective, or on their permanence in the cellular structures when imagistic detection is sought.

In order establish the dark cytotoxicity profile, the new mesoporphyrinic complexes were evaluated in vitro using HT29 (human colon adenocarcinoma) cell line for different doses and incubation times. For this purpose the cellular viability and proliferative capacity were assessed upon each round of cell incubation with the synthesized metalloporphyrins.

Viability assay at short-time incubation stressed the point that at low loading doses $(1-5 \mu \mathrm{M})$ there are no differences between the two porphyrinic complexes behavior. For doses greater than $5 \mu \mathrm{M}$, only Zn(II)TCMPOHp induces an increase in the LDH release by HT29 cells (Figure 3a). The effect of the metallic ion of the porphyrinic complex on the cell viability is highlighted at $24 \mathrm{~h}$ of incubation and for concentrations higher than $5 \mu \mathrm{M}$. In these conditions, only $\mathrm{Cu}(\mathrm{II}) \mathrm{TCMPOHp}$ has a visible influence on the cell viability (Figure $3 b$ ).

Figure 3. The viability of HT29 cells incubated $2 \mathrm{~h}$ (a) and $24 \mathrm{~h}$ (b) with $\mathrm{Zn}$ (II)TCMPOHp and $\mathrm{Cu}(\mathrm{II}) \mathrm{TCMPOHp}$; the $\mathrm{LDH}$ release registered as OD at $490 \mathrm{~nm}$.

a

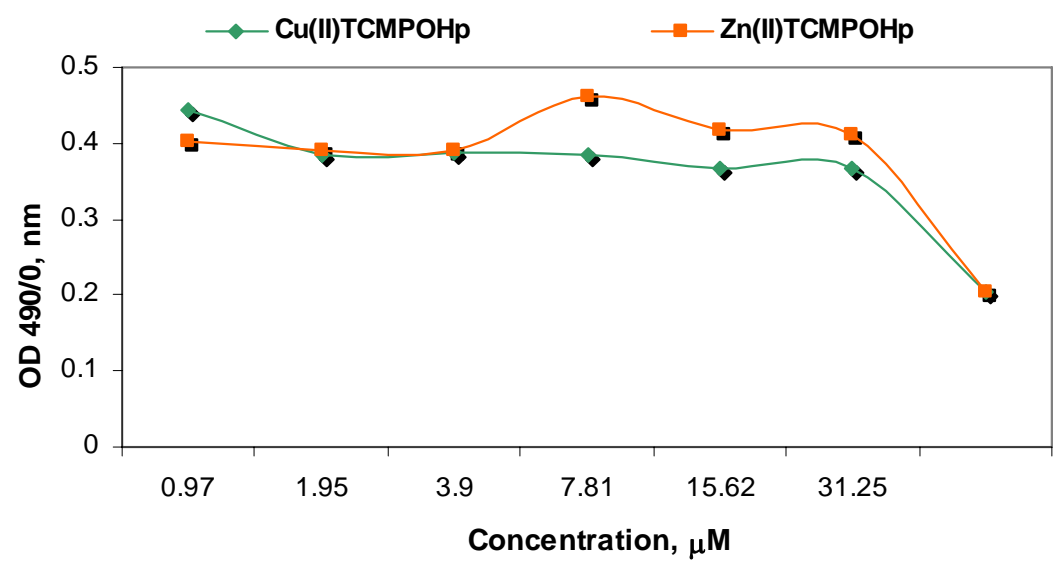


Figure 3. Cont.

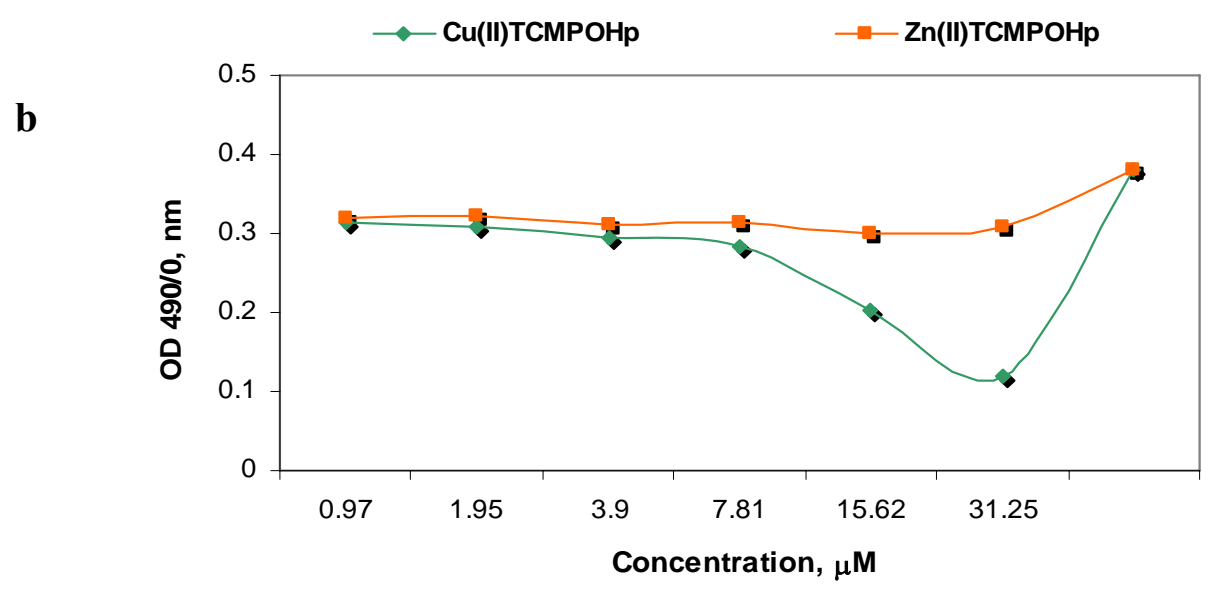

Proliferative capacity assay performed following two hours incubation suggests slight differences between the compounds (Figure 4a). The $3.95 \mu \mathrm{M}$ concentration results in a homogeneous cell response for both compounds. $\mathrm{Cu}(\mathrm{II}) \mathrm{TCMPOHp}$ inhibits the cellular proliferation only in concentrations higher than $10 \mu \mathrm{M}$. Following 24 hours incubation Zn(II)TCMPOHp maintains its nontoxic characteristics related to the proliferative function of the cells, while for $\mathrm{Cu}(\mathrm{II}) \mathrm{TCMPOHp}$ the effect is dose-dependent (Figure 4b).

Figure 4. The proliferation of HT29 cells incubated $2 \mathrm{~h}$ (a) and $24 \mathrm{~h}$ (b) with $\mathrm{Zn}(\mathrm{II}) \mathrm{TCMPOH}_{\mathrm{p}}$ and $\mathrm{Cu}(\mathrm{II}) \mathrm{TCMPOH}_{\mathrm{p}}$; the $\mathrm{MTS}$ reduction reaction registered as OD at 490/620 nm.

a

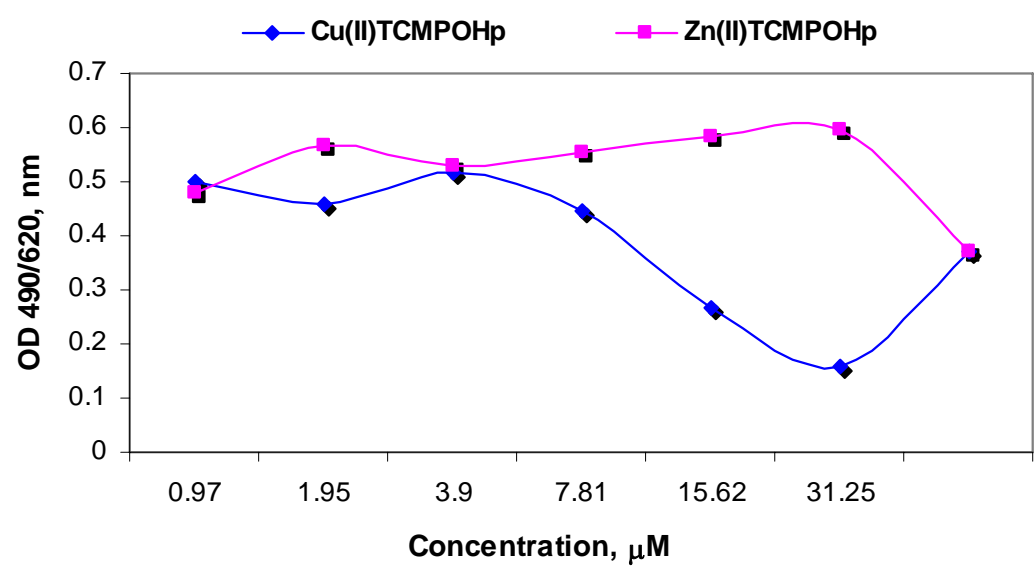

b

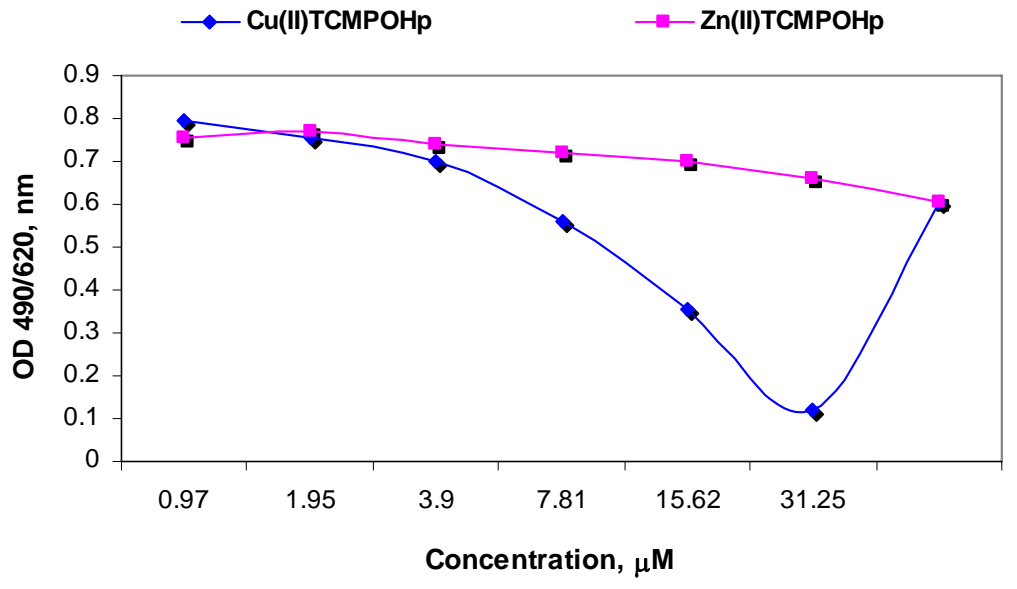




\section{Experimental}

\subsection{Materials and Methods}

Commercially available chemicals and solvents were used as received from Sigma-Aldrich and Merck. For the microwave assisted synthesis, a domestic microwave oven was used, with temperature and power control. The elemental analysis of $\mathrm{C}, \mathrm{H}$ and $\mathrm{N}$ was performed with an automatic Carlo Erba L-1108 analyzer. IR spectra were recorded with a FT-IR 400D Nicolet Impact spectrophotometer. The substances under analysis, previously dried for $24 \mathrm{~h}$ at $150{ }^{\circ} \mathrm{C}$, were processed as $\mathrm{KBr}$ (spectrally pure) pellets. The spectra were recorded in the 4,000-500 $\mathrm{cm}^{-1}$ spectral range. The molecular absorption spectra of the mesoporphyrinic complexes were recorded with the use of a Lambda 35 Perkin-Elmer spectrophotometer in different solvents $\left(\mathrm{MeOH}, \mathrm{EtOH}\right.$, iso-PrOH, DMF, DMSO, $\left.\mathrm{CH}_{2} \mathrm{Cl}_{2}\right)$ using a $10 \mathrm{~mm}$ path length quartz cell, in single beam mode. Fluorescence spectra were recorded with a Jasco FP 6500 spectrofluorimeter.

The metalloporphyrin solutions were freshly prepared in the spectrally pure solvents at the concentration $2.5 \times 10^{-6} \mathrm{M}$ and kept in dark until the measurement to prevent photodegradation. The NMR spectra of the zinc porphyrinic complex were recorded with a $400 \mathrm{MHz}$ Bruker NMR spectrometer. EPR spectra of the copper porphyrinic complex were recorded on powders at room temperature using a ART-6 spectrometer, operating in the X band $(9.01 \mathrm{GHz})$, equipped with a field modulation unit of $100 \mathrm{KHz}$.

The preliminary toxicological studies in the presence of the unsymmetrical mesoporphyrinic complexes consisted in viability and proliferation studies performed on human colon adenocarcinoma cell line HT29. The HT29 cell line was purchased from the European Collection of Cell Cultures (ECACC, catalog no. 91072201) and cultured in RPMI 1640 medium supplemented with $100 \mathrm{U} / \mathrm{mL}$ penicillin, $0.1 \mathrm{mg} / \mathrm{mL}$ streptomycin, $0.25 \mu \mathrm{g} / \mathrm{mL}$ amphotericin, $2 \mathrm{mM}$ glutamine and $10 \%$ fetal bovine serum. The cells were maintained at $37^{\circ} \mathrm{C}$ in a $5 \% \mathrm{CO}_{2}$ humid atmosphere for standard cultivation and during all the toxicological tests.

The porphyrinic complexes solutions were handled under sterile conditions. Ten mM stock solutions of the compounds to be tested were prepared in DMSO by sonication at $22,000 \mathrm{~Hz}$ for 30 seconds. For the toxicological tests the solutions were further diluted in RPMI 1640 culture medium for the toxicological tests in the range $0.97-31.25 \mu \mathrm{M}$.

For the viability and the proliferation test assay, the cells (cell density $5 \times 10^{-4}$ cells $/ \mathrm{mL}$ ) were incubated with each of the tested concentrations for 2 and $24 \mathrm{~h}$. A cellular control consisting in unloaded/untreated HT29 cells was used for every replicate of the tests, corresponding to each incubation time.

For cellular viability we have used lactate dehydrogenase (LDH) release test [42], using CytoTox 96® Non-Radioactive Cytotoxicity Test (Promega). For testing cell proliferation by means of the tetrazolium salt (MTS) reduction test [43], we have used CellTiter 96® AQeous One Solution Cell Proliferation Assay kit (Promega). Briefly, at end of each incubation time with the mesoporphyrinic complexes, the cell supernatants were collected for LDH test whilst the cell sediment was used for MTS assay. Results were expressed as triplicate's mean of optical density (OD) $\pm \mathrm{SD}$, recorded on a 
Jasco V630 spectrophotometer, in a single beam mode, at $490 \mathrm{~nm}$ without any reference (for LDH release in the cell viability test) and at $490 \mathrm{~nm}$ with reference at $640 \mathrm{~nm}$ (for MTS reduction test).

3.2. Synthesis of 5-(4-hydroxyphenyl)-10, 15, 20-tris-(4-carboxymethylphenyl)-21, 23-Zn(II)-porphine $(\mathrm{Zn}(\mathrm{II}) \mathrm{TCMPOH})$

A mixture of 4-hydroxybenzaldehyde (1.12 g, $0.01 \mathrm{~mol})$, methyl 4-formyl benzoate (4.92 $\mathrm{g}$, $0.03 \mathrm{~mol})$, freshly distilled pyrrole $(2.76 \mathrm{~mL}, 0.04 \mathrm{~mol})$, anhydrous zinc chloride $(1.36 \mathrm{~g}, 0.01 \mathrm{~mol})$ and 2-3 g of silica gel $60(200-500 \mu \mathrm{m}, 35-70 \mathrm{mesh})$ in the presence of 2,6-dimethylpyridine $(1 \mathrm{~mL})$ was irradiated in a Pyrex bottle with a microwave oven set at $175^{\circ} \mathrm{C}, 450 \mathrm{~W}$ for $10 \mathrm{~min}$. Extraction of samples for monitoring the synthesis by UV-Vis spectroscopy was performed after every 2 min of irradiation.

The crude product was first dissolved in dichloromethane, then filtered and finally purified on a chromatography column by repeated elution, using silica gel (100-200 mesh size) as stationary phase and dichloromethane as eluent. The solution of the zinc porphyrinic complex was concentrated by simple distillation. The obtained violet crystals were dried at $\approx 100{ }^{\circ} \mathrm{C}$ for $12 \mathrm{~h}$. The compound of interest was obtained with a yield of about $48 \%$. Elemental analysis for $\mathrm{C}_{50} \mathrm{H}_{34} \mathrm{~N}_{4} \mathrm{O}_{7} \mathrm{Zn}$ : calculated $\mathrm{C}$ 69.2, H 3.92, N 6.45; found C 69.04, H 3.80, N 6.28. ${ }^{1} \mathrm{H}-\mathrm{NMR}: \delta_{\mathrm{H}}\left(400 \mathrm{MHz}, \mathrm{CDCl}_{3}\right), \mathrm{ppm}: 4.13$ $\left(9 \mathrm{H}, \mathrm{s}, \mathrm{O}-\mathrm{CH}_{3}\right), 6.5(1 \mathrm{H}, \mathrm{s}$, brs., $\mathrm{OH}), 8.00\left(2 \mathrm{H}, \mathrm{d}, \mathrm{H}_{\text {metha-Ph-OH }}\right), 8.2\left(2 \mathrm{H}, \mathrm{d}, \mathrm{H}_{\text {ortho-Ph-OH }}\right), 8.3(6 \mathrm{H}, \mathrm{d}$,

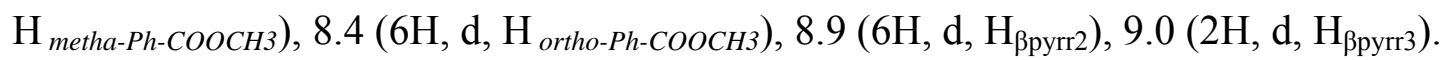

The comparative study of the ${ }^{1} \mathrm{H}-\mathrm{NMR}$ data of the unsymmetrical mesoporphyrinic ligand and its zinc complex reveals the absence of the signal at $-2.78(2 \mathrm{H}, \mathrm{s}, \mathrm{N}-\mathrm{H})$ [32], indicating the involvement of both nitrogen atoms of porphyrinic ring in the coordination after deprotonation. Other signals in the NMR spectrum of the complex are similar to those of the ligand.

3.3. Synthesis of 5-(4-hydroxyphenyl)-10, 15, 20-tris-(4-carboxymethylphenyl)-21, 23-Cu(II)-porphine $\left(\mathrm{Cu}(\mathrm{II}) \mathrm{TCMPOH}_{\mathrm{P}}\right)$

A mixture of anhydrous $\mathrm{CuCl}_{2}(1.34 \mathrm{~g}, 0.01 \mathrm{~mol})$, methyl 4-formyl benzoate (4.92 g, $\left.0.03 \mathrm{~mol}\right)$, 4hydroxybenzaldehyde $(1.12 \mathrm{~g}, 0.01 \mathrm{~mol})$, freshly distilled pyrrole $(2.76 \mathrm{~mL}, 0.04$ moli), $2-3 \mathrm{~g}$ of silica gel $60(200-500 \mu \mathrm{m}, 35-70 \mathrm{mesh})$ and 2,6-dimethylpyridine $(1 \mathrm{~mL})$ was irradiated in a microwave oven at $180^{\circ} \mathrm{C}, 475 \mathrm{~W}$, for $8 \mathrm{~min}$. The extent of the complexation reaction was monitored by UV-Vis spectroscopy and for this purpose extraction of samples was performed after every 2 min of irradiation.

The product was dissolved in dichloromethane, filtered and then purified on a chromatography column. The solid product was chromatographed on silica gel (100-200 mesh size) with dichloromethane as eluent. The solution of the copper porphyrinic complex was concentrated by simple distillation. The obtained dark red crystals were dried at $\approx 100{ }^{\circ} \mathrm{C}$ for $12 \mathrm{~h}$.

The copper unsymmetrical porphyrinic complexes were obtained with a yield of about $52 \%$. Elemental analysis for $\mathrm{C}_{50} \mathrm{H}_{34} \mathrm{~N}_{4} \mathrm{O}_{7} \mathrm{Cu}$ : calculated $\mathrm{C} 69.32, \mathrm{H} 3.93, \mathrm{~N} 6.47$; found $\mathrm{C} 69.19, \mathrm{H} \mathrm{3.82,} \mathrm{N}$ 6.36. The EPR parameters are: $\mathrm{g}_{\|}=2.172, \mathrm{~g}_{\perp}=2.050, \mathrm{~A}_{\|}=202 \mathrm{G}, \mathrm{A}_{\perp}=30 \mathrm{G}$. These values are in good agreement with literature data and confirm a square planar geometrical arrangement of nitrogen atoms around the copper ion $[44,45]$. Also, the $\mathrm{g}_{\|}$value $\left(\mathrm{g}_{\|}<2.3\right)$ indicates a covalent character of the $\mathrm{Cu}-\mathrm{N}$ bonds in the copper-porphyrinic complex [46]. 


\section{Conclusions}

The paper describes the microwave irradiation assisted synthesis, spectral properties and preliminary cytotoxicity investigation of some new unsymmetrical porphyrinic complexes, namely 5(4-hydroxyphenyl)-10,15,20-tris-(4-carboxymethylphenyl)-21,23-Zn(II)-porphine and 5-(4-hydroxyphenyl)-10, 15, 20-tris-(4-carboxymethylphenyl)-21,23-Cu(II)-porphine. These complexes were synthesized for use as active substances in the photodiagnosis and photodynamic therapy of cancer.

The syntheses of the copper and zinc porphyrinic complexes were confirmed by FT-IR, UV-Vis, EPR and NMR analysis. The influence of environment polarity on the wavelengths of the absorbance and fluorescence band maxima is also described. The spectral changes that occur by increasing environmental polarity can be ascribed to the physical interaction between the porphyrinic substituents and the solvent molecules.

Both tetrapyrrolic complexes were evaluated in terms of cytotoxicity using HT29 (human colon adenocarcinoma) cell line for different doses and incubation times. The results showed no significant toxicity on the investigated cell line and suggest that these novel complexes are promising active substances for the photodiagnosis and photodynamic therapy use.

\section{Acknowledgements}

The research was supported by CNMP project No. 41-047/2007, granted from the Romanian Ministry of Education, Research, Youth and Sport. The author thanks Carolina Constantin from "Victor Babes" National Institute of Pathology, Bucharest, Romania, for experimental assistance in preliminary cytotoxicity investigation of the newly synthesized porphyrinic complexes.

\section{References and Notes}

1. Detty, M.R.; Gibson, S.L.; Wagner, S.J. Current Clinical and Preclinical Photosensitizers for Use in Photodynamic Therapy. J. Med. Chem. 2004, 47, 3897-3915.

2. Kamuhabwa, A.; Agostinis, P.; Ahmed, B.; Landuyt, W.; Van Cleynenbreugel, B.; Van Poppel, H.; De Witte, P. Hypericin as a potential phototherapeutic agent in superficial transitional cell carcinoma of the bladder. Photochem. Photobiol. Sci. 2004, 3, 772-780.

3. Hilderbrand, S.; Weissleder, R. Near-infrared fluorescence: Application to in vivo molecular imaging, Curr. Opin. Chem. Biol. 2010, 14, 71-79.

4. Chatterjee, D.K.; Fong, L.S.; Zhang, Y. Nanoparticles in photodynamic therapy: An emerging paradigm. Adv. Drug Deliv. Rev. 2008, 60, 1627-1637.

5. Bonneau, S.; Bizet, C.V.; Mojzisova, H.; Brault, D. Tetrapyrrole-photosensitizers vectorization and plasma LDL: A physic-chemical approach. Int. J. Pharm. 2007, 344, 78-87.

6. Chin, W.W.L.; Lau, O.W.K.; Bhuvaneswari, R.; Heng, P.W.S.; Olivo, M. Chlorin e6-polyvinylpyrrolidone as a fluorescent marker for fluorescence diagnosis of human bladder cancer implanted on the chick chorioallantoic membrane model, Cancer Lett. 2007, 245, 127-133.

7. Mora, J.S.; Cormick, P.M.; Milanesio, E.M. Durantini, E.N. The photodynamic activity of a novel porphyrin derivative bearing a fluconazole structure in different media and against Candida albicans, Dyes Pigments 2010, 87, 234-240. 
8. Banfi, S.; Caruso, E.; Buccafurni, L; Battini, V.; Zazzaron, S.; Barbieri, P.; Orlandi, V. Antibacterial activity of tetraaryl-porphyrin photosensitizers: An in vitro study on Gram negative and Gram positive bacteria. J. Photochem. Photobiol. B-Biol. 2006, 85, 28-38.

9. Cormick, P.M.; Alvarez, G.; Rovera, M.; Durantini, E.N. Photodynamic inactivation of Candida albicans sensitized by tri- and tetra-cationic porphyrin derivatives Eur. J. Med. Chem. 2009, 44, 1592-1599.

10. Munin, E.; Giroldo, L.M.; Alves, L.P.; Costa, M.S. Study of germ tube formation by Candida albicans after photodynamic antimicrobial chemotherapy (PACT). J. Photochem. Photobiol. B-Biol. 2007, 88, 16-20.

11. Stockert, J.C.; Cañete, M.; Juarranz, A.; Villanueva, A.; Horobin, R.W.; Borrell, J.I.; Teixidó, J.; Nonell, S. Porphycenes: Facts and Prospects in Photodynamic Therapy of Cancer. Curr. Med. Chem. 2007, 14, 997-1026.

12. Banfi, S.; Caruso, E.; Caprioli, S.; Mazzagatti, L.; Canti, G.; Ravizza, R.; Gariboldia, M.; Montia, E. Photodynamic effects of porphyrin and chlorin photosensitizers in human colon adenocarcinoma cells. Bioorg. Med. Chem. 2004, 12, 4853-4860.

13. Chen, J.Y.; Mak, N.K.; Yow, C.M.N.; Fung, M.C.; Chiu, L.C.; Leung, W.N.; Cheung, N.H. The Binding Characteristics and Intracellular Localization of Temoporfin (mTHPC) in Myeloid Leukemia Cells: Phototoxicity and Mitochondrial Damage. Photochem. Photobiol. 2000, 72, 541-547.

14. Grosseweiner, L.I. The Science of Phototherapy; CRC Press: London, UK, 1994; Chapter 8, pp. 139-155.

15. Schweiter, C.; Schmidt, R. Physical Mechanisms of Generation and Deactivation of Singlet Oxygen. Chem. Rev. 2003, 103, 1685-1758.

16. Bonnett, R. Chemical Aspects of Photodynamic Therapy. In Advanced Chemistry Texts; Gordon and Breach Science Publishers: Amsterdam, The Netherlands, 2000; Volume 1, pp. 57-112.

17. Postino, F.; Mora, M.; DeMadariaga, M.A.; Nonell, S.; Sagrista, M.L. Incorporation of hydrophobic porphyrins into liposomes: Characterization and structural requirements. Int. J. Pharma. 2004, 278, 239-254.

18. Scalise, I.; Durantini, E.N. Photodynamic effect of metallo 5-(4-carboxyphenyl)-10,15,20-tris(4methylphenyl) porphyrins in biomimetic AOT reverse micelles containing urease. J. Photochem. Photobiol. A 2004, 162, 105-113.

19. Boyle, R.B.; Dolphin, D. Structure and Biodistribution Relationships of Photodynamic Sensitizers. Photochem. Photobiol. 1996, 64, 469-485.

20. Mac Donald, I.J.; Dougherty, T.J. Basic principles of photodynamic therapy. J. Porphyrins Phthalocyanines 2001, 5, 105-129.

21. Nyman, E.S.; Hynninen, P.H. Research advances in the use of tetrapyrrolic photosensitizers for photodynamic therapy. J. Photochem. Photobiol. B-Biol. 2004, 73, 1-28.

22. Kessel, D. Correlation between subcellular localization and photodynamic efficacy. J. Porphyrins Phthalocyanines 2004, 8, 1009-1014.

23. Rosenkranz, A.A.; Jans, D.A.; Sobolev, A.S. Targeted intracellular delivery of photosensitizers to enhance photodynamic efficiency. Immunol. Cell Biol. 2002, 78, 452-464. 
24. Osterloh, J.; Vicente, M.G.H. Mechanisms of porphyrinoid localization in tumors. J. Porph. Phthal. 2002, 5, 305-325.

25. Milgrom, L.; MacRobert, S.; Light years ahead. Chem. Brit. 1998, 34, 45-50.

26. Adam, D. Microwave chemistry: Out of the kitchen. Nature 2003, 421, 571-572.

27. Wei, T.H. Microwave-assisted synthesis and reverse saturable absorption of phthalocyanines and porphyrins. J. Organomet. Chem. 2004, 689, 1078-1084.

28. Liu, M.O.; Hu, A.T. Microwave-assisted synthesis of phthalocyanine-porphyrin complex and its photoelectric conversion properties. J. Organomet. Chem. 2004, 689, 2450-2455.

29. Lindsey, J.S. Synthetic Routes to meso-Patterned Porphyrins. Acc. Chem. Res. 2010, 43, 300-311.

30. Senge, M.O. Nucleophilic Substitution as a Tool for the Synthesis of Unsymmetrical Porphyrins. Acc. Chem. Res. 2005, 38, 733-743.

31. Senge, M.O.; Shaker, Y.M.; Pintea, M.; Ryppa, C.; Hatscher, S.S.; Ryan, A.; Sergeeva, Y. Synthesis of meso-substituted ABCD-type porphyrins by functionalization reactions. Eur. J. Org. Chem. 2010, 2, 237-258.

32. Socoteanu, R.; Boscencu, R.; Nacea, V.; Constantin, C.; Manda, G.; Neagu, M.; Ilie, M.; Oliveira, A.S.; Vieira Ferreira, L.F. Bio functionalized porphyrinic compound has tetrapyrrolic heterocycles class, synthesized and optimized for cellular load assays. Romanian Patent Application No 0200900452/17.06.2009, published in the Official Bulletin of Intelectual Property (BOPI) 11/2009 with No.125018AO.

33. Gouterman, M. Optical Spectra and Electronic Structure of Porphyrins and Related Rings. In The Porphyrins; Dolphin, D., Ed.; Academic Press: New York, NY, USA, 1978; Volume 3, pp. 11-87.

34. Boscencu, R.; Socoteanu, R.; Oliveira, A.S.; Vieira Ferreira, L.F.; Nacea, V.; Patrinoiu, G.; Synthesis and Characterization of Some Unsymmetrically-substituted Mesoporphyrinic MonoHydroxyphenyl Complexes of Copper(II). Pol. J. Chem. 2008, 82, 509-522.

35. Boscencu, R.; Socoteanu, R.; Oliveira, A.S.; Ferreira, L.F.V. Studies on Zn(II) monohydroxyphenyl mesoporphyrinic complexes. Synthesis and characterization. J. Serb. Chem. Soc. 2008, 73, 713-726.

36. Boscencu, R.; Ilie, M.; Socoteanu, R.; Oliveira, A.S.; Constantin, C.; Neagu, M.; Manda, G.; Vieira Ferreira, L.F. Microwave Synthesis, Basic Spectral and Biological Evaluation of Some Copper (II) Mesoporphyrinic Complexes, Molecules 2010, 15, 3731-3743.

37. Boscencu, R.; Socoteanu, R.; Ilie, M.; Oliveira, A.S.; Constantin, C.; Vieira Ferreira, L.F. Synthesis, Spectral and Biological Evaluation of Some Mesoporphyrinic Zn(II) Complexes. Rev. Chim. 2009, 10, 1006-1011.

38. Reichardt, C.H. Solvent effects on the absorption spectra of organic compounds, In Solvents and Solvent Effects in Organic Chemistry; VCH: New York, NY, USA, 1988; pp. 329-352.

39. Gouterman, M.; Wagniere, G.H.; Snyder, L.C. Spectra of porphyrins: Part II. Four orbital model, J. Mol. Spectrosc. 1963, 11, 108-127.

40. Allison, R.R.; Sibata, C.H. Oncologic photodynamic therapy photosensitizers: A clinical review, Photodiagnosis Photodyn. Ther. 2010, 7, 61-75. 
41. Pandey, R.K.; Goswami, L.N.; Chen, Y.; Gryshuk, A.; Missert, J.R.; Oseroff, A.; Dougherty, T.J.; Nature: A rich source for developing multifunctional agents. Tumor - imaging and photodynamic therapy. Lasers Surg. Med. 2006, 38, 445-467.

42. Korzeniewski, C.; Callewaert, D.M. An enzyme-release assay for natural cytotoxicity. J. Immunol. Meth. 1983, 64, 313-320.

43. Barltrop, J.A.; Owen, T.C.; Cory, A.H.; Cory, J.G. 5-(3-carboxymethoxyphenyl)-2-(4,5dimethylthiazolyl)-3-(4-sulfophenyl)tetrazolium, inner salt (MTS) and related analogs of 3-(4,5dimethylthiazolyl)-2,5-diphenyltetrazolium bromide (MTT) reducing to purple water-soluble formazans as cell-viability indicators. Bioorg. Med. Chem. Lett. 1991, 1, 611-614.

44. Lin, W.C. Electron Spin Resonance and Electronic Structure of Metalloporphyrins. In The Porphyrins; Dolphin, D., Ed.; Academic Press: New York, NY, USA, 1978; Volume 4, pp. 358-364.

45. Manoharan, P.T.; Roger, M.T. ESR study of copper (II) and silver (II) tetraphenylporphyrin. In Electron Spin Resonance of Metal Complexes; Yen, T.F., Ed.; Plenum Press; New York, NY, USA, 1969; pp. 143-173.

46. Kivelson, D.; Neiman, R.R. ESR Studies on the Bonding in Copper Complexes. J. Chem. Phys. 1961, 35, 149-155.

Sample Availability: Samples of the compounds are available from the authors.

(C) 2011 by the authors; licensee MDPI, Basel, Switzerland. This article is an open access article distributed under the terms and conditions of the Creative Commons Attribution license (http://creativecommons.org/licenses/by/3.0/). 